\title{
Assessing of genotoxicity of 16 centralized source-waters in China by means of the SOS/umu assay and the micronucleus test: Initial identification of the potential genotoxicants by use of a GC/MS method and the QSAR Toolbox 3.0
}

\author{
Yan Ye ${ }^{a}$, Jiang Weiwei ${ }^{\mathrm{b}}$, Li Na $^{\mathrm{b}}$, Ma Mei ${ }^{\mathrm{a}, *}$, Wang Donghong ${ }^{\mathrm{a}}$, \\ Wang Zijian ${ }^{\mathrm{a}, *}$, Rao Kaifeng ${ }^{\mathrm{b}}$ \\ a State Key Laboratory of Environmental Aquatic Chemistry, Research Center for Eco-Environmental Sciences, Chinese Academy of Sciences, Beijing 100085, \\ China \\ ${ }^{\mathrm{b}}$ National Engineering Research Center of Urban Water Resources, Shanghai 200082, China
}

\section{A R T I C L E I N F O}

\section{Article history:}

Received 1 February 2013

Received in revised form

10 September 2013

Accepted 2 November 2013

Available online 10 February 2014

\section{Keywords:}

\section{Genotoxicity}

Centralized source waters

SOS/umu test

MN test

Genotoxicants

\begin{abstract}
A B S T R A C T
Only few studies were conducted to assess genotoxicity of centralized source waters in China and almost none of them dealt with the causal relationship between the genotoxic effect and genotoxicants. In this work, 16 centralized source waters in China were sampled from five river systems and genotoxicity of their organic extracts was assessed by use of the SOS/umu test for DNA-damaging effect and the miniaturized flow cytometry-based micronucleus (MN) test for chromosome-damaging effect. In addition, initial identification of potential genotoxicants for the six samples from the Yangtze River was done with a GC/MS method and the QSAR toolbox 3.0. The results demonstrate that eight samples showed both indirect and direct DNA-damaging effects, another four samples showed only indirect DNA-damaging effects, while chromosome-damaging effects were found for 14 out of the 16 samples, in which aneugenic and clastogenic modes of action were found for 4 and 10 samples, respectively. Both direct/indirect DNAdamaging effects and chromosome-damaging effects were induced by the six Yangtze River samples, and the existing different types of genotoxicant confirmed the results. Furthermore, $o$-phenylphenol was initially identified as the major cause for the DNA-damaging effects while PAHs, pesticides, phenol and anthraquinone were identified as ubiquitous chromosome-damaging agents among these samples. In conclusion, a combination of the SOS/umu test and the miniaturized flow cytometry-based MN test to detect both DNA-damaging and chromosome-damaging effects could be used as a comprehensive genotoxicity assessment tool for the evaluation and classification of genotoxicity of complex mixtures, and potential genotoxicants can be initially identified with additional information from chemical analysis and the QSAR toolbox.
\end{abstract}

(c) 2014 Published by Elsevier B.V.

\section{Introduction}

Drinking water affects human beings so directly that human health is closely associated with the degree of contamination of water bodies. Over the past several decades, with excessive pursuit of industrialization, the irresponsible location of factories and the excessive use of herbicides and pesticides, the deterioration of source-water quality in China has been highlighted [1-3].

\footnotetext{
* Corresponding authors at: State Key Laboratory of Environmental Aquatic Chemistry, Research Center for Eco-Environmental Sciences, 18 Shuangqing Road, Haidian District, Beijing 100085, China. Tel.: +86 106284 9141; fax: +861062923543.

E-mail addresses: mamei@rcees.ac.cn (M. Mei), wangzijian@rcees.ac.cn (W. Zijian).
}

Recently, most attention was paid to source-water contaminants that can disrupt the endocrine system in both humans and in wildlife organisms $[4,5]$. In contrast, little information is available on contaminants with capability of inducing damage to DNA or chromosomes [6]. Epidemiological studies in China among populations exposed to drinking-water contaminated with genotoxins have suggested a relationship between mutagenicity of drinkingwater and cancers of the liver, stomach and esophagus $[7,8]$. Therefore, particular attention should be paid to the genotoxicity of source waters in China.

At present, several guidelines have already been published to determine genotoxicity of pharmaceuticals and commercial chemicals $[9,10]$. Given that no single test has the capability to detect all genotoxic mechanisms, these recommendations have suggested the use of a battery of bioassays to achieve a comprehensive 
assessment addressing two types of genetic damage of concern, i.e., DNA damage and chromosome damage. For the purpose of a comprehensive evaluation of genotoxicity of source waters, the application of a battery of bioassays to rapidly screen the exposure and to determine potential effects of genotoxins can provide an ideal way to assess the total genotoxicity of mixtures.

The SOS/umu test is one of the short-term, high-throughput genotoxicity tests for detecting DNA-damaging agents. It has been widely used for evaluating genotoxic compounds and for screening of genotoxicity of water bodies [11-13]. In addition, indirect DNAdamaging agents that need activation to show their damaging effects were successfully determined by use of exogenous metabolizing enzymes (S9) $[14,15]$. On the other hand, a miniaturized flow-cytometry based MN test was recently developed to detect chromosome damage, and it is now well proven that this method is a high-throughput technique capable of demonstrating both aneugenic and clastogenic effects simultaneously [16]. Given that p53 deficiency and inaccurate toxicity measurement are the two major reasons resulting in the seemingly high rate of false or misleading positive results, p53-proficient human hepatic cell lines (Hep G2) and more sensitive measurements of toxicity are better choices $[17,18]$. For this reason information on the two levels of DNA damage and chromosomal damage, including clastogenicity and aneugenicity, can be obtained to provide a comprehensive assessment of the genotoxic potential of source waters.

A causal relationship has been established between genotoxic effects and potential genotoxicants in native hospital wastewater [19] and ground waters [12]. However, due to the existence of various chemical contaminants at low concentrations in source waters and the lack of data on genotoxicity of many pollutants, identifying the chemical responsible for genotoxicity is not an easy task with respect to source waters. Recently, the availability of analytic methods for simultaneous analysis of organic contaminants makes it possible to quickly and sensitively determine possible pollutants in different water bodies [20]. The QSAR Toolbox comprises software developed to fill gaps in (eco-)toxicological data for assessment of chemical hazards, and to provide robust categorization of chemicals suitable to fill data gaps in genetic toxicity. Thus, the presence of possible genotoxic pollutants in source waters could be quickly screened by the simultaneous analysis of organic contaminants and the QSAR Toolbox. This would then provide valuable information for initial identification of genotoxic pollutants responsible for DNA- and chromosome-damaging effects.

The primary objective of the present study, therefore, was to comprehensively evaluate the genotoxicity of organic extracts of 16 source waters in China, employing the in vitro SOS/umu bioassay with Salmonella typhimurium TA 1535/pSK 1002 and the miniaturized flow cytometry-based MN test with metabolically competent human hepatoma cells (Hep G2), in combination with chemical analysis to initially identify genotoxicants responsible for the specific genotoxic risks.

\section{Materials and methods}

\subsection{Chemicals}

Benzo(a)pyrene (BaP, CAS 50-32-8), 4-nitroquinoline- $N$-oxide (4-NQO, CAS 56-57-5), dimethyl sulfoxide (DMSO, CAS 67-68-5), propidium iodide (PI, CAS 25535-16-4), and $o$-nitrophenyl- $\beta$-D-galactopyranoside (ONPG, CAS 396-07-3) were purchased from Sigma-Aldrich. HPLC-grade dichloromethane and methanol were purchased from Fisher Scientific (Fair Lawn, NJ). RNAse A was bought from Tiangen biotech cooperation (Beijing China). Other reagents used for bacterial or cell culturing, cell staining or lysis were purchased from reliable sources and were of the highest standard commercially available.

\subsection{Sample collection and preparation}

Source-water samples (20 L) were collected from 16 sites including rivers and reservoirs from China between March 2010 and August 2010 (Table 1 and Fig. 1).
Table 1

Sampling locations of the 16 source-waters.

\begin{tabular}{|c|c|c|c|}
\hline & Label & Type & Coordinate \\
\hline \multirow[t]{2}{*}{ Songhua River } & S1 & River & $126.501 \mathrm{E}, 45.764 \mathrm{~N}$ \\
\hline & S2 & Reservoir & $127.697 \mathrm{E}, 44.399 \mathrm{~N}$ \\
\hline \multirow[t]{2}{*}{ Liao River } & S3 & Reservoir & $124.101 \mathrm{E}, 41.886 \mathrm{~N}$ \\
\hline & S4 & Reservoir & $125.404 \mathrm{E}, 41.292 \mathrm{~N}$ \\
\hline \multirow[t]{6}{*}{ Yangtze River $^{\mathrm{a}}$} & S5 & River & $106.554 \mathrm{E}, 29.570 \mathrm{~N}$ \\
\hline & S6 & River & $106.529 \mathrm{E}, 29.508 \mathrm{~N}$ \\
\hline & S7 & River & $106.449 \mathrm{E}, 29.597 \mathrm{~N}$ \\
\hline & S8 & River & $118.694 \mathrm{E}, 31.994 \mathrm{~N}$ \\
\hline & S9 & River & $118.798 \mathrm{E}, 32.142 \mathrm{~N}$ \\
\hline & S10 & River & $118.717 \mathrm{E}, 32.049 \mathrm{~N}$ \\
\hline \multirow[t]{3}{*}{ Huai River } & $\mathrm{S} 11$ & River & $118.950 \mathrm{E}, 33.586 \mathrm{~N}$ \\
\hline & S12 & River & $119.000 \mathrm{E}, 33.625 \mathrm{~N}$ \\
\hline & S13 & River & $118.972 \mathrm{E}, 33.509 \mathrm{~N}$ \\
\hline \multirow[t]{3}{*}{ Pearl River } & $\mathrm{S} 14$ & Reservoir & $114.149 \mathrm{E}, 22.57 \mathrm{~N}$ \\
\hline & S15 & Reservoir & $114.603 \mathrm{E}, 23.794 \mathrm{~N}$ \\
\hline & S16 & River & $113.259 \mathrm{E}, 23.807 \mathrm{~N}$ \\
\hline
\end{tabular}

HLB cartridges $\left(\right.$ Oasis $^{\circledR}$ ) pre-conditioned with $5 \mathrm{~mL}$ methanol and $5 \mathrm{~mL}$ water were applied to obtain the organic extracts on the spot and then brought back to laboratory in darkness at $4{ }^{\circ} \mathrm{C}$. The columns were thereafter eluted with $5 \mathrm{~mL} \mathrm{CH} \mathrm{Cl}_{2}$ and $5 \mathrm{~mL} \mathrm{CH} \mathrm{Cl}_{2} / \mathrm{CH}_{3} \mathrm{OH}$ (9:1), followed by filtration over anhydrous sodium sulfate to remove water. The dehydrated extracts were evaporated to near dryness in a rotary evaporator (R-200, Buchi, France), and the residue was blown to dryness with a gentle flow of nitrogen. Except for the six samples collected from the Yangtze River, the other ten samples were directly reconstituted in $0.2 \mathrm{~mL}$ DMSO and stored at $-20^{\circ} \mathrm{C}$ for the in vitro bioassays. For the six samples collected from Yangtze River, $0.2 \mathrm{~mL}$ hexane were added to the residues and $0.02 \mathrm{~mL}$ were transferred and diluted in $0.2 \mathrm{~mL}$ hexane and stored in the dark at $-20^{\circ} \mathrm{C}$ until chemical analysis. The remaining $0.18 \mathrm{~mL}$ of each sample was further blown to dryness under nitrogen, reconstituted in $0.18 \mathrm{~mL}$ DMSO, and stored at $-20^{\circ} \mathrm{C}$ for the in vitro bioassays.

\subsection{In vitro bioassays}

\subsubsection{The SOS/umu bioassay}

The SOS/umu test was carried out according to the method of Oda et al. and Wittekindt et al., with some modifications $[13,21]$. In the present study, the test strain S. typhimurium TA1535/pSK1002 was pre-cultured in L-Broth medium in an incubator at $37^{\circ} \mathrm{C}, 198 \mu \mathrm{L}$ exponentially growing bacteria were mixed with $2-\mu \mathrm{L}$ samples into each well of the 96-well microplate (Corning $\left.{ }^{\circledR}\right)$. For the determination of indirect genotoxins, liver $9000 \times g$ supernatant fraction (S9, obtained from Oriental Yeast, Tokyo) and cofactors were mixed $(4.8 \mathrm{~mL}$ bacterial culture with $1 \mathrm{~mL}$ S9 mixture) before the sample was added. After incubation at $37^{\circ} \mathrm{C}, 800 \mathrm{rpm}$ for $4.5 \mathrm{~h}$, the density of the strain was monitored by measuring the absorbance at $595 \mathrm{~nm}$ with $150 \mu \mathrm{L}$ culture in a microplate reader (Tecan M200, Switzerland). For the determination of $\beta$-galactosidase activity, $20 \mu \mathrm{L}$ of the culture was mixed with $210 \mu \mathrm{L}$ Z-buffer $(0.1 \mathrm{M}$ sodium phosphate $\mathrm{pH} 7.4,10 \mathrm{mM} \mathrm{KCl}, 1 \mathrm{mM} \mathrm{MgSO}$ containing $1 \mathrm{mg} \mathrm{L}^{-1}$ mercaptoethanol, $10 \mu \mathrm{L}$ of $1 \mathrm{mg} / \mathrm{mL} \mathrm{SDS}$, and $5 \mu \mathrm{L}$ chloroform) and the enzymatic reaction was started by adding $40 \mu \mathrm{L}$ of $4 \mathrm{mg} / \mathrm{mL} 0$-nitrophenyl- $\beta$-Dgalactopyranoside (ONPG, Sigma-Aldrich Fluka, USA). After $20 \mathrm{~min}$ reaction at $37^{\circ} \mathrm{C}$ and $800 \mathrm{rpm}, 30 \mu \mathrm{L} \mathrm{Na}_{2} \mathrm{CO}_{3}(1 \mathrm{M})$ was added to stop the reaction. The absorbance at $420 \mathrm{~nm}$ and $550 \mathrm{~nm}$ was measured for $150-\mu \mathrm{L}$ aliquots of the reaction mixture. DMSO was used as solvent control, and 4-NQO and $\mathrm{BaP}$ were used as positive controls in the absence and presence of S9, respectively. The $\beta$-galactosidase activity (Unit) was calculated as follows:

$\beta-$ Galactosidase activity (Unit) $=1000 * \frac{(\text { Abs420 }-1.75 * \text { Abs550) }}{(t * 0.0667 * \text { Abs595) }}$

where Abs420, Abs550 and Abs595 were the absorbance at $420 \mathrm{~nm}, 550 \mathrm{~nm}$ and $595 \mathrm{~nm}$, and $\mathrm{t}$ represents the reaction time ( $\mathrm{min}$ ).

The data interpretation was based on Xiao et al. [22]. In general, the sample is considered to be positive (+) only when a significant dose-response relationship is shown. The genotoxic potency of positive samples is assessed by use of the TEQ approach [12]. Briefly, the equivalent 4-NQO concentration $\left(\mathrm{TEQ}_{4-\mathrm{NOO}}\right)$ and $\mathrm{BaP}$ concentration $\left(\mathrm{TEQ}_{\mathrm{BaP}}\right)$ of concentrated source waters were calculated based on the dose-response curves for 4-NQO and $\mathrm{BaP}$. To quantitatively express the direct and indirect genotoxic potency of the source-water samples, the equations used are listed below:

$\mathrm{TEQ}_{4-\mathrm{NQO}}\left(\mu \mathrm{g} \mathrm{L}^{-1}\right)=$ Slope $_{\text {sample }} /$ Slope $_{4-\mathrm{NQO}}$

$\mathrm{TEQ}_{\mathrm{BaP}}\left(\mu \mathrm{g} \mathrm{L}^{-1}\right)=$ Slope $_{\text {sample }} /$ Slope $_{4-\mathrm{B} a \mathrm{P}}$ 




Fig. 1. Sampling locations:

) river; ( $\Delta$ ) reservoir.

where Slope 4 -NQO, Slope $_{4-\mathrm{BaP}}$ and Slope $_{\text {sample }}$ represent the slope values of the linear part of the linear fitted dose-response curves of 4-NQO (Unit/ $\mu$ g 4-NQO),


source water).

\subsubsection{The flow cytometry-based micronucleus assay}

The p53-proficient Hep G2 cells were used to avoid using S9-mixture because a certain level of metabolism is present in Hep G2 cells in vitro [23]. The flow cytometry-based micronucleus test, data calculation and interpretation were carried out according to the protocols published by Bryce et al., and OECD [16,24]. Briefly, exponentially growing Hep G2 cells were transferred at a density of about $1.35 \times 10^{4}$ cells per well into flat-bottom Corning ${ }^{\circledR} 48$-well plates, $12 \mathrm{~h}$ prior to the exposure with test samples to allow cells to sufficiently attach to the plate. Eight double-diluted concentration series and triplicates for each sample were performed. After a 36-h exposure (1.5 normal cell doublings), the cells were rinsed three times with $300 \mu \mathrm{L}$ cold PBS and $125 \mu \mathrm{L} \mathrm{FCMI}$ (584 $\mathrm{mg} \mathrm{L}^{-1}$ sodium chloride, $1 \mathrm{mg} \mathrm{L}^{-1}$ sodium citrate, $50 \mu \mathrm{g} \mathrm{mL}^{-1}$ PI, $50 \mu \mathrm{g} \mathrm{mL}^{-1}$ RNase A, and $0.3 \mathrm{mLL}^{-1}$ NonidetP-40) were then added and the samples placed at room temperature in the dark. After $1 \mathrm{~h}$ incubation, an equal amount of FCMII (1.5\% citric acid and $0.25 \mathrm{M}$ sucrose, $50 \mu \mathrm{g} \mathrm{mL}^{-1} \mathrm{PI}$ ) with counting beads $\left(6 \mu \mathrm{m}\right.$, PeakFlow ${ }^{\mathrm{TM}}$ Flow Cytometry Reference Beads, Invitrogen, Cat\# P-14828) was added for another $30 \mathrm{~min}$.

The counting beads were used to calculate the cell viability which was described by Bryce et al. [25], and cytotoxicity was described as percentage relative survival (\% RS). The samples were gently tapped up and down to re-suspend the cells before analysis of micronuclei (MN) and nuclei. A single-laser flow cytometer, 488-nm excitation (FACSCalibur, BD Biosciences, San Jose, CA) was employed for data acquisition and analysis. MN ratio, mean fluorescence of MN and hypodiploid ratio (\% hypodiploid nuclei) were simultaneously calculated and used to classify aneugenic and clastogenic modes of action (MOA). In brief, the clastogenic effect was assigned to samples that significantly induced $\mathrm{MN}$, but did not markedly affect hypodiploid ratio and mean fluorescence of MN. The aneugenic effect was assigned to samples that significantly induced MN, along with markedly increased hypodiploid ratio and mean fluorescence.

\subsection{Automatic screening of non-target organic pollutants}

The Agilent 6890 GC (Agilent Technologies) with an Agilent 5975 mass-selective detector equipped with a DB-5 M capillary column ( $30 \mathrm{~m} \times 0.25 \mathrm{~mm} \times 0.25 \mu \mathrm{m}$, J\&W Sci., USA) was used here for automatic screening and identifying the possible contaminants in the six Yangtze River source waters. In the present study, Hazardous Contaminant Database (HCD) and Pesticide and Endocrine Disruptor Database were used, and these two databases totally include 1655 chemicals covering a wide range of contaminants, including pesticides and their metabolites, endocrine disruptors, important polychlorinated biphenyls (PCBs), PAHs, some dyes (e.g., sudan red), organophosphorus fire retardants, etc. Retention-time locking, data acquisition, processing, and instrumental control were performed with the Agilent MSD ChemStation software (E02.00 Version, Agilent Technologies, USA). The inlet temperature was $300^{\circ} \mathrm{C}$, and in the splitless mode with a $1-\mu \mathrm{L}$ injection. The oven temperature program was $40^{\circ} \mathrm{C}, 10^{\circ} \mathrm{C} / \mathrm{s}$ to $300^{\circ} \mathrm{C}$, which was kept for $15 \mathrm{~min}$. The carrier gas used was helium in constant pressure mode, and the retention time was locked by fluoranthene. Mass-selective detector was performed in scan mode. Acquisition mass ranged from 50 to 500 U. De-convolution Reporting Software (A.04.00 version, Agilent Technologies) was used to identify the compounds in the studied matrices. The de-convolution parameters in the Automatic Mass Spectral De-convolution and Identification System (AMDIS) were as follows: resolution: high; sensitivity: high; shape requirements: medium; scan direction: high to low. The results of SOS/umu test and in vitro MN test were first taken from published documents. Given the high concordance of about $90 \%$ between SOS/umu test and Ames test [14], the results obtained by Ames test were used for SOS/umu test if results of SOS/umu test were not available. As for chemicals missing in vitro $\mathrm{MN}$ test results, the results of in vivo MNt and in vitro chromosomal aberration test were then considered. The data gap where all the experimental data were missing is filled by QSAR Toolbox Version 3.0 with the Read-Across method described by OECD [26]. The results were presented as: positive (+); negative (-). If conflicting results were obtained between documents and databases, only the positive results were taken according to the precautionary principle.

\section{Results}

A concentration-dependent increase in $\beta$-galactosidase activity was observed when the strain Salmonella typhimurium TA1535/pSK1002 was exposed to 12 organic extracts of the total 16 water sources in the absence of S9 and the genotoxic potencies of these positive samples are shown in Fig. 2. The positive samples in the SOS/umu test without S9 were source waters collected from the Songhua River, Yangtze River and Huai River, and the $\mathrm{TEQ}_{4 \text {-NOO }}$ value ranged from 0.0066 to $0.3462 \mu \mathrm{g} \mathrm{L}^{-1}$, with a mean of $0.020 \mu \mathrm{gL}^{-1}$. The highest genotoxic potencies were found for S5 and S7, with $0.03462 \pm 0.00368 \mu \mathrm{g} \mathrm{L}^{-1}$ and $0.03401 \pm 0.00295 \mu \mathrm{g} \mathrm{L}^{-1} \mathrm{TEQ}_{4-\mathrm{NQO}}$, respectively. And for the reservoirs including S3, S4, S14 and S15 no dose-dependent increase was observed; they were considered as negative samples here. In the presence of S9, a concentration-dependent increase in $\beta$ galactosidase activity was found for eight samples, six of which were from the Yangtze River. The values of $\mathrm{TEQ}_{\mathrm{B} a \mathrm{P}}$ for positive samples were between 0.1052 and $0.2616 \mu \mathrm{g} \mathrm{L}^{-1}$ and the highest genotoxic potencies were found for samples S7 and S8, with $0.2565 \pm 0.0269 \mu \mathrm{g} \mathrm{L}^{-1}$ and $0.2616 \pm 0.1098 \mu \mathrm{g} \mathrm{L}^{-1} \mathrm{TEQ}_{\mathrm{B} a \mathrm{P}}$, respectively. Four samples including S1, S2, S12 and S13 came out positive 


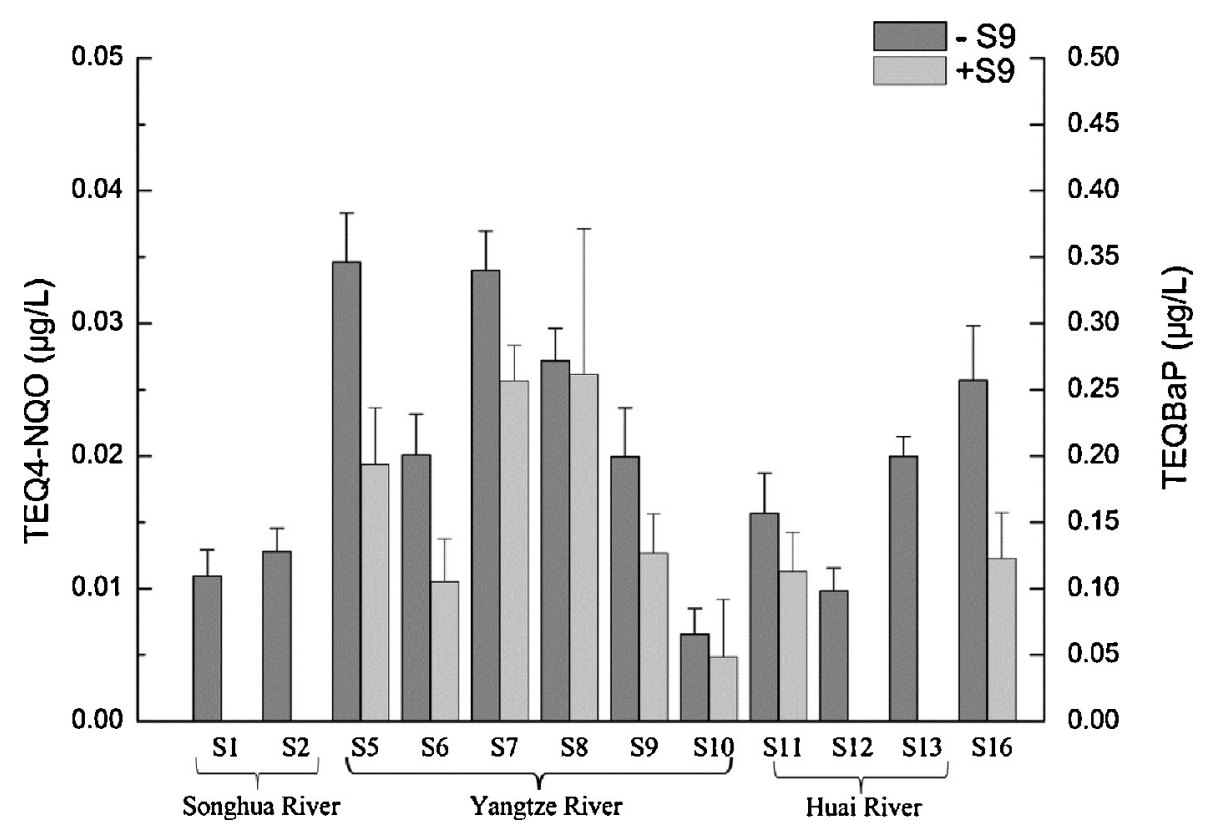

Fig. 2. $\mathrm{TEQ}_{4-\mathrm{NQO}}$ and $\mathrm{TEQ}_{\mathrm{B} a \mathrm{P}}$ values of positive source waters. Error bars represent the standard deviation of replicate $(n=4)$.

in the absence of S9, but were not able to induce an SOS effect when tested in the presence of S9.

MN frequency, cytotoxicity, mean fluorescence of MN and the frequency of hypodiploid nuclei (HN) are provided in Table 2. When HepG2 cells were exposed to the organic extracts of source waters, except for S1 and S13, the other 14 samples significantly and dose-dependently induced MN, at concentrations with RS \% more than about $40 \%$. For these positive samples, the MOA signatures were determined to distinguish aneugenic from clastogenic effects. Increasing MN percent, along with the higher mean fluorescence and hypodiploid ratio were found in six of the 14 positive samples including S4, S10, S11, S12, S14 and S16, which clearly indicated an aneugenic mode of action. In contrast, the \% hypodiploid cells and the mean fluorescence did not show a significant increase in the remaining eight samples, where the MN ratio was found to be significantly increased. The highest increase of MN percent was found in the sample collected from S4 with a 4.47-fold increase at the highest acceptable concentration, and a clastogenic effect was induced. The highest increase of MN percent induced by an aneugenic effect was found for S16, with a 3.81-fold increase at the highest concentration studied.

The summarized results of the MN test and the SOS/umu assay for all samples are given in Table 3. Besides for samples from S11 and S16, direct and indirect DNA-damaging effects and chromosome-damaging effects were also found for samples from S5 to S11, which were collected from the Yangtze River. For samples S2 and S12, both indirect DNA-damaging effects and chromosomedamaging effects were found. Only indirect DNA-damaging effects were found for samples S1 and S13, while only chromosomedamaging effects were observed for samples S3, S4, S14 and S15.

For the initial identification of the possible genotoxicants in S5, S6, S7, S8, S9 and S10, the compounds that could be of interest were identified and the potential genotoxic properties of the existing pollutants are listed in Table 4 . The results demonstrate that a total of 39 compounds were identified, among which most were pesticides and PAHs. The following compounds were detected in all samples: tributyl phosphate, dimethyl phthalate, dibutyl phthalate, benzophenone and dibenzofuran. There were six DNAdamaging agents among the 39 identified compounds; only one DNA-damaging agent, 0 -phenylphenol, was detected with frequencies higher than $80 \%$. On the other hand, 23 chromosome-damaging agents were found with fluoranthene, fluorene, naphthalene, acenaphthene, o-phenylphenol, isoprothiolane, phenol, atrazine and anthraquinone being detected with frequencies higher than $80 \%$.

\section{Discussion}

The strain S. typhimurium TA1535/pSK1002 employed in the in vitro SOS/umu test has a deficient lipopolysaccharide and contains umuDC-lacZ genes. These features allow the in vitro bioassay to provide sensitive and simultaneous detection of singlestranded DNA, tri-nucleotides, oligo-nucleotides, DNA adducts, DNA dimers, oxidative DNA damage, and gene-mutation like point- and frameshift-mutations simultaneously [27,28]. In the absence of S9, a direct DNA-damaging effect was detected in all the river source-water samples and in reservoir source-water S2, while negative responses were found upon treatment with the other reservoir source-waters. Higher genotoxic potencies were found for samples collected from the Yangtze River and the Pearl River in the most developed region in China, receiving industry waste-water and sewage of urban living discharged from different sources [29]. When samples were incubated with S9, indirect DNAdamaging effects were still observed for S5, S6, S7, S8, S9, S10, S11, and $S 16$, which clearly indicates that genetic toxicants in these centralized source waters were both direct and indirect DNA-damaging agents. Although studies have been reported on the genotoxicity of source waters in the Yangtze River [6,30], the differences in sample preparation and genotoxicity endpoint can obviously hamper a detailed comparison of test results.

Recently, a variety of known or unknown genotoxic compounds have become components of surface waters [31]. Several DNAdamaging agents, such as fluoroquinolone (FQ) antibiotics and nitroarenes, were identified as major mutagens in waters by combination of the SOS/umu test as a genotoxicity bioassay and HPLC as a fractionation method. Hartmann et al. [19] used HPLC coupled with fluorescence detection to quantify fluoroquinolone antibiotics, and found one major DNA-damaging agent (ciprofloxacin) in the wastewater of a hospital in Switzerland. Ma et al. [12] used S. typhimurium strain TA1535/pSK100 and the $O$-acetyltransferaseoverexpressing strain NM 2009 in different fractions of river waters in the Jialu River basin, China, and found that flumequine and 
Table 2

Flow cytometry-based Hep G2 MN test result.

\begin{tabular}{|c|c|c|c|c|c|c|c|c|}
\hline \multirow[t]{2}{*}{ Sample Site } & \multirow[t]{2}{*}{ Conc. (ml/well) } & \multirow[t]{2}{*}{ Cyto. (\%RS) } & \multicolumn{3}{|l|}{ Micronuclei } & \multicolumn{2}{|c|}{ Hypodiploid nuclei } & \multirow[t]{2}{*}{$\mathrm{MOA}^{\mathrm{b}}$} \\
\hline & & & Percent (\%) & Fold increase & Mean fluorescence & Percent (\%) & Fold increase & \\
\hline \multirow[t]{5}{*}{ S1 } & 0.00 & 100.00 & 3.36 & 1.00 & 23.25 & 1.22 & 1.00 & \multirow[t]{5}{*}{ Non-genotoxic } \\
\hline & 2.34 & 98.90 & 3.90 & 1.16 & 23.15 & 1.28 & 1.05 & \\
\hline & 4.69 & 90.10 & 3.91 & 1.16 & 22.02 & 1.50 & 1.23 & \\
\hline & 9.36 & 90.65 & 4.38 & 1.30 & 22.55 & 1.31 & 1.07 & \\
\hline & 18.75 & 81.72 & 3.94 & 1.17 & 22.15 & 1.20 & 0.98 & \\
\hline \multirow[t]{5}{*}{ S2 } & 0.00 & 100.00 & 3.36 & 1.00 & 23.25 & 1.22 & 1.00 & \multirow[t]{5}{*}{ Clastogenic } \\
\hline & 2.34 & 101.26 & 4.39 & 1.31 & 22.53 & 1.46 & 1.20 & \\
\hline & 4.69 & 98.32 & 4.60 & 1.37 & 23.02 & 1.41 & 1.16 & \\
\hline & 9.36 & 77.17 & 4.41 & 1.31 & 23.18 & 1.34 & 1.10 & \\
\hline & 18.75 & 54.23 & 5.53 & $1.65^{\mathrm{a}}$ & 23.03 & 1.38 & 1.13 & \\
\hline \multirow[t]{5}{*}{ S3 } & 0.00 & 100.00 & 4.85 & 1.00 & 23.60 & 2.59 & 1.00 & Clastogenic \\
\hline & 2.34 & 93.29 & 7.37 & 1.52 & 22.83 & 2.12 & 0.82 & \\
\hline & 4.69 & 91.30 & 7.77 & 1.60 & 22.97 & 2.20 & 0.85 & \\
\hline & 9.38 & 70.25 & 9.45 & $1.95^{\mathrm{a}}$ & 23.79 & 2.29 & 0.88 & \\
\hline & 18.75 & 61.56 & 11.45 & $2.36^{\mathrm{a}}$ & 24.26 & 5.18 & 2.00 & \\
\hline S4 & 0.00 & 100.00 & 4.85 & 1.00 & 23.60 & 2.59 & 1.00 & Aneugenic \\
\hline & 2.34 & 82.73 & 7.13 & $1.47^{\mathrm{a}}$ & 23.17 & 2.58 & 1.00 & \\
\hline & 4.69 & 94.50 & 8.69 & $1.79^{\mathrm{a}}$ & 23.08 & 2.38 & 0.92 & \\
\hline & 9.38 & 81.30 & 10.26 & $2.12^{\mathrm{a}}$ & 23.28 & 6.51 & 2.51 & \\
\hline & 18.75 & 58.47 & 21.67 & $4.47^{a}$ & 24.48 & 17.47 & 6.75 & \\
\hline S5 & 0.00 & 100.00 & 4.85 & 1.00 & 23.60 & 2.59 & 1.00 & Clastogenic \\
\hline & 2.34 & 86.10 & 9.00 & $1.86^{\mathrm{a}}$ & 23.12 & 2.90 & 1.12 & \\
\hline & 4.69 & 83.35 & 10.28 & $2.12^{\mathrm{a}}$ & 23.43 & 1.93 & 0.75 & \\
\hline & 9.38 & 73.79 & 11.51 & $2.37^{\mathrm{a}}$ & 23.58 & 2.11 & 0.81 & \\
\hline & 18.75 & 58.32 & 13.50 & $2.78^{a}$ & 24.39 & 2.62 & 1.01 & \\
\hline S6 & 0.00 & 100.00 & 4.85 & 1.00 & 23.60 & 2.59 & 1.00 & Clastogenic \\
\hline & 2.34 & 86.75 & 7.90 & $1.63^{\mathrm{a}}$ & 22.95 & 2.43 & 0.94 & \\
\hline & 4.69 & 86.39 & 8.37 & $1.73^{\mathrm{a}}$ & 23.08 & 2.22 & 0.86 & \\
\hline & 9.38 & 70.67 & 9.58 & $1.98^{\mathrm{a}}$ & 23.56 & 2.20 & 0.85 & \\
\hline & 18.75 & 57.42 & 11.23 & $2.32^{\mathrm{a}}$ & 23.95 & 1.92 & 0.74 & \\
\hline S7 & 0.00 & 100.00 & 4.85 & 1.00 & 23.60 & 2.59 & 1.00 & Clastogenic \\
\hline & 2.34 & 84.19 & 8.49 & $1.75^{\mathrm{a}}$ & 23.37 & 2.25 & 0.87 & \\
\hline & 4.69 & 93.20 & 8.41 & $1.73^{\mathrm{a}}$ & 23.20 & 2.69 & 1.04 & \\
\hline & 9.38 & 76.49 & 10.99 & $2.27^{\mathrm{a}}$ & 23.81 & 2.92 & 1.13 & \\
\hline & 18.75 & 43.98 & 17.93 & $3.70^{\mathrm{a}}$ & 24.99 & 6.36 & 2.46 & \\
\hline S8 & 0.00 & 100.00 & 6.20 & 1.00 & 22.89 & 2.57 & 1.00 & Clastogenic \\
\hline & 2.34 & 100.30 & 7.56 & 1.22 & 24.33 & 1.72 & 0.67 & \\
\hline & 4.69 & 90.24 & 9.03 & 1.46 & 23.93 & 1.85 & 0.72 & \\
\hline & 9.38 & 82.76 & 9.40 & $1.52^{\mathrm{a}}$ & 23.72 & 2.12 & 0.82 & \\
\hline & 18.75 & 64.33 & 1016 & $1.64^{\mathrm{a}}$ & 24.29 & 2.24 & 0.87 & \\
\hline S9 & 0.00 & 100.00 & 6.20 & 1.00 & 22.89 & 2.57 & 1.00 & Clastogenic \\
\hline & 2.34 & 93.05 & 9.01 & 1.45 & 23.23 & 2.27 & 0.88 & \\
\hline & 4.69 & 86.29 & 9.78 & $1.58^{\mathrm{a}}$ & 23.29 & 2.23 & 0.87 & \\
\hline & 9.38 & 96.46 & 9.12 & $1.47^{\mathrm{a}}$ & 23.16 & 2.50 & 0.97 & \\
\hline & 18.75 & 61.57 & 10.41 & $1.68^{\mathrm{a}}$ & 24.83 & 2.49 & 0.97 & \\
\hline S10 & 0.00 & 100.00 & 6.20 & 1.00 & 22.89 & 2.57 & 1.00 & Aneugenic \\
\hline & 4.69 & 84.23 & 8.48 & 1.37 & 23.13 & 1.89 & 0.74 & \\
\hline & 9.38 & 96.26 & 8.08 & 1.30 & 24.12 & 1.93 & 0.75 & \\
\hline & 18.75 & 69.26 & 9.67 & $1.56^{\mathrm{a}}$ & 24.35 & 2.52 & 0.98 & \\
\hline & 37.50 & 44.48 & 12.92 & $2.08^{a}$ & 25.22 & 3.05 & 1.19 & \\
\hline S11 & 0.00 & 100.00 & 7.21 & 1.00 & 18.30 & 6.72 & 1.00 & Aneugenic \\
\hline & 1.17 & 98.37 & 7.84 & 1.09 & 18.26 & 7.26 & 1.08 & \\
\hline & 2.34 & 91.24 & 8.61 & 1.19 & 18.64 & 7.92 & 1.18 & \\
\hline & 4.69 & 67.07 & 12.50 & $1.73^{\mathrm{a}}$ & 18.75 & 11.05 & 1.64 & \\
\hline & 9.36 & 42.95 & 13.97 & $1.94^{\mathrm{a}}$ & 18.96 & 12.26 & 1.82 & \\
\hline $\mathrm{S} 12$ & 0.00 & 100.00 & 7.21 & 1.00 & 18.30 & 6.72 & 1.00 & Aneugenic \\
\hline & 1.17 & 101.07 & 7.67 & 1.06 & 18.47 & 7.12 & 1.06 & \\
\hline & 2.34 & 87.29 & 9.25 & 1.28 & 18.31 & 8.42 & 1.25 & \\
\hline & 4.69 & 77.86 & 10.97 & $1.52^{\mathrm{a}}$ & 18.96 & 9.89 & 1.47 & \\
\hline & 9.36 & 38.92 & 15.36 & $2.13^{a}$ & 18.93 & 13.18 & 1.96 & \\
\hline $\mathrm{S} 13$ & 0.00 & 100.00 & 3.36 & 1.00 & 23.25 & 1.22 & 1.00 & Non-genotoxic \\
\hline & 0.59 & 97.50 & 3.86 & 1.15 & 22.93 & 1.24 & 1.02 & \\
\hline & 1.17 & 88.00 & 3.58 & 1.07 & 23.05 & 1.30 & 1.07 & \\
\hline & 2.34 & 91.99 & 3.45 & 1.03 & 22.61 & 0.88 & 0.72 & \\
\hline & 4.69 & 71.23 & 4.34 & 1.29 & 23.27 & 1.76 & 1.44 & \\
\hline
\end{tabular}


Table 2 (Continued)

\begin{tabular}{|c|c|c|c|c|c|c|c|c|}
\hline \multirow[t]{2}{*}{ Sample Site } & \multirow[t]{2}{*}{ Conc. (ml/well) } & \multirow[t]{2}{*}{ Cyto. (\%RS) } & \multicolumn{3}{|l|}{ Micronuclei } & \multicolumn{2}{|c|}{ Hypodiploid nuclei } & \multirow[t]{2}{*}{$\mathrm{MOA}^{\mathrm{b}}$} \\
\hline & & & Percent (\%) & Fold increase & Mean fluorescence & Percent (\%) & Fold increase & \\
\hline \multirow[t]{5}{*}{ S14 } & 0.00 & 100.00 & 6.90 & 1.00 & 24.00 & 2.91 & 1.00 & \multirow{5}{*}{ Aneugenic } \\
\hline & 1.17 & 93.03 & 7.75 & 1.12 & 24.70 & 2.42 & 0.83 & \\
\hline & 2.34 & 81.21 & 8.58 & 1.24 & 23.82 & 2.84 & 0.98 & \\
\hline & 4.69 & 75.54 & 11.15 & 1.62 & 24.49 & 2.82 & 0.97 & \\
\hline & 9.36 & 44.47 & 14.80 & 2.14 & 25.37 & 5.01 & 1.72 & \\
\hline \multirow[t]{5}{*}{ S15 } & 0.00 & 100.00 & 6.90 & 1.00 & 24.00 & 2.91 & 1.00 & \multirow[t]{5}{*}{ Clastogenic } \\
\hline & 9.36 & 82.51 & 9.58 & 1.39 & 24.01 & 1.92 & 0.66 & \\
\hline & 18.75 & 86.57 & 10.54 & $1.53 \mathrm{a}$ & 24.15 & 2.19 & 0.75 & \\
\hline & 37.50 & 75.53 & 11.43 & $1.66 \mathrm{a}$ & 24.48 & 2.58 & 0.89 & \\
\hline & 75.00 & 66.91 & 13.05 & $1.89 \mathrm{a}$ & 24.53 & 2.72 & 0.93 & \\
\hline \multirow[t]{5}{*}{ S16 } & 0.00 & 100.00 & 6.90 & 1.00 & 24.00 & 2.91 & 1.00 & \multirow[t]{5}{*}{ Aneugenic } \\
\hline & 2.34 & 93.78 & 10.10 & 1.46 & 24.17 & 1.95 & 0.67 & \\
\hline & 4.69 & 95.78 & 10.63 & 1.54 & 23.73 & 2.37 & 0.81 & \\
\hline & 9.36 & 69.69 & 15.46 & $2.24^{\mathrm{a}}$ & 25.31 & 5.83 & 2.00 & \\
\hline & 18.75 & 42.07 & 26.27 & $3.81^{\mathrm{a}}$ & 26.42 & 16.47 & 5.66 & \\
\hline
\end{tabular}

a MN ratio significantly increased compared with concurrent solvent control (one-way ANOVA, $p<0.05$ ).


fluorescence of MN. The aneugenic MOA was assigned to samples that significantly induced MN, along with markedly increased hypodiploid ratio and mean fluorescence.

Table 3

Summary of MN-assay results and SOS/umu test results: “+”: positive; “-”: negative.

\begin{tabular}{|c|c|c|c|c|c|c|c|c|c|}
\hline \multirow[t]{2}{*}{ Sample site } & \multicolumn{2}{|c|}{ SOS/umu test } & \multirow[t]{2}{*}{ MN test } & \multirow[t]{2}{*}{ Type } & \multirow[t]{2}{*}{ Sample site } & \multirow{2}{*}{$\begin{array}{l}\text { SOS/umu test } \\
\text {-S9 }\end{array}$} & \multirow[b]{2}{*}{ +S9 } & \multirow[t]{2}{*}{ MN test } & \multirow[t]{2}{*}{ Type } \\
\hline & $-\mathrm{S9}$ & $+\mathrm{S} 9$ & & & & & & & \\
\hline $\mathrm{S} 1$ & + & - & - & Reservoir & $59^{a}$ & + & + & + & River \\
\hline $\mathrm{S} 2$ & + & - & + & River & $\mathrm{S} 10^{\mathrm{a}}$ & + & + & + & River \\
\hline S3 & - & - & + & Reservoir & S11 & + & + & + & River \\
\hline $\mathrm{S} 4$ & - & - & + & Reservoir & $\mathrm{S} 12$ & + & - & + & River \\
\hline $\mathrm{S} 5^{\mathrm{a}}$ & + & + & + & River & $\mathrm{S} 13$ & + & - & - & River \\
\hline$S 6^{a}$ & + & + & + & River & $\mathrm{S} 14$ & - & - & + & Reservoir \\
\hline$S 7^{\mathrm{a}}$ & + & + & + & River & S15 & - & - & + & Reservoir \\
\hline$S 8^{a}$ & + & + & + & River & S16 & + & + & + & River \\
\hline
\end{tabular}

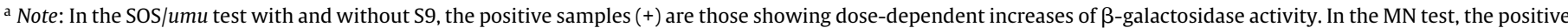
samples (+) are those showing dose-dependent increases of MN ratio.

a Selected for chemical analysis.

nitroarenes were the putative DNA-damaging agents. According to the results of the qualitative analysis for organic pollutants in the six selected source-waters in the Yangtze River, more than one DNA-damaging agent was found for all six source waters and $o$-phenylphenol was identified as a DNA-damaging agent in all samples except S10. This confirmed the results we obtained with the SOS/umu test, i.e., that DNA-damaging effects were induced for all six samples. On the other hand, regarding the significantly lower genotoxic potency of S10 compared with the other source waters in the Yangtze River, o-phenylphenol might be a major pollutant in these source waters. However without quantitative analysis, a further causal relationship between DNA-damaging effect and putative DNA-damaging agent cannot be established.

The flow cytometry-based micronucleus test was recently developed to distinguish an aneugenic from a clastogenic mode of action and therefore provides a comprehensive way to determine chromosome damage. Bryce et al. [16] first developed this method and successfully applied it to measure aneugens, clastogens and non-genotoxins. We here investigated the genotoxic potential of centralized source water and the possible mechanisms, while using for the first time the newly developed bioassay with Hep G2 cells. This metabolically competent human hepatoma cell line has retained the activities of various enzymes which are essential for activation and detoxification of genotoxins. Hep G2 cells have been widely employed to determine chromosomal damage induced by genotoxic agents and complex mixtures [32,33]. In addition, it has been reported to be successfully used to discriminate aneugens and clastogens with signature of micronucleus size in a high-throughput screening system [34]. In combination with the flow cytometry-based MN test with Hep G2, the centralized source waters in this study were designated as either non-genotoxic or aneugenic or clastogenic, which indicates that along with the MN counts the information on genotoxic modes of action was simultaneously acquired in the present analytical platform.

Numerous chromosome-damaging agents were identified in the six centralized Yangtze River source-waters. These pollutants clearly confirmed the results of chromosome-damaging effects induced by these samples. Moreover, PAHs such as fluoranthene, fluorene, naphthalene and acenaphthene, pesticides such as $o$-phenylphenol, isoprothiolane and atrazine, phenol and anthraquinone were found to be ubiquitous chromosomedamaging agents among the selected samples, in accordance with other studies which demonstrated that PAHs or pesticides were widespread in the Yellow River [35], the Pearl River delta [36], and in the Yangtze River [37] in China. Although little information is currently available on the detailed mode of action for specific chromosome-damaging agents, the induction of chromosomedamaging effect was caused by a clastogenic mode of action for S5, S6, S7, S8, S9, and an aneugenic mode of action for S10, providing valuable information to establish a further causal relationship.

It is concluded that genotoxic risk screened by the in vitro SOS/umu test can be different in the in vitro miniaturized MN test, according to the genotoxicity results of S1, S3, S4, S13, S14 and S15. This reflects the differences both in the nature of the two assays and the genotoxicants in the samples. The SOS/umu test detects DNA-damaging agents while the miniaturized MN test detects chromosome-damaging effects $[16,27,28]$. The complexity of the mixtures and mechanisms involved, therefore, makes the 
Table 4

Results of automatic screening of non-target compounds.

\begin{tabular}{|c|c|c|c|c|c|c|c|c|c|}
\hline \multirow[t]{2}{*}{ Chemicals } & \multirow[t]{2}{*}{ CAS } & \multicolumn{2}{|l|}{ Endpoint } & \multicolumn{6}{|c|}{ Sample sites } \\
\hline & & $\overline{\mathrm{DD}^{\mathrm{a}}}$ & $\mathrm{CA}^{\mathrm{b}}$ & $\overline{S 5}$ & S6 & S7 & S8 & S9 & $\overline{S 10}$ \\
\hline Fluoranthene & $206-44-0$ & $-[26]^{\mathrm{c}}$ & $+^{R}$ & $\sqrt{ }$ & & $\sqrt{ }$ & & $\sqrt{ }$ & $\sqrt{ }$ \\
\hline Isophorone & $78-59-1$ & $+(-S 9)[15]^{\mathrm{c}}$ & $+[27]$ & & & & $\sqrt{ }$ & & \\
\hline Nitrobenzene & $98-95-3$ & $-[28]^{c}$ & $+[29]$ & & & & $\sqrt{ }$ & $\sqrt{ }$ & $\sqrt{ }$ \\
\hline Fluorene & $86-73-7$ & $-[26]^{c}$ & $+\mathrm{R}$ & $\sqrt{ }$ & & $\sqrt{ }$ & $\sqrt{ }$ & $\sqrt{ }$ & $\sqrt{ }$ \\
\hline Triadimefon & $43121-43-3$ & $-{ }^{\mathrm{R}}$ & $-^{\mathrm{R}}$ & & $\sqrt{ }$ & & & & \\
\hline Triadimenol & $55219-65-3$ & $-^{\mathrm{R}}$ & $-^{\mathrm{R}}$ & & $\sqrt{ }$ & & & & \\
\hline Pyrene & $129-00-0$ & $-[14]^{\mathrm{c}}$ & $+[29]$ & & $\sqrt{ }$ & & $\sqrt{ }$ & $\sqrt{ }$ & $\sqrt{ }$ \\
\hline Nicotine & $54-11-5$ & $-[26]^{c}$ & $+d$ & & $\sqrt{ }$ & & $\sqrt{ }$ & $\sqrt{ }$ & \\
\hline Naphthalene & $91-20-3$ & $-[26]^{\mathrm{c}}$ & $+[29]$ & $\sqrt{ }$ & & & $\sqrt{ }$ & $\sqrt{ }$ & $\sqrt{ }$ \\
\hline 2,6-Dichloro-4-nitrobenzenamine & $99-30-9$ & $+(-S 9,+S 9)^{d}$ & ${ }^{\mathrm{R}}$ & & & & $\sqrt{ }$ & $\sqrt{ }$ & $\sqrt{ }$ \\
\hline Tributyl phosphate & $126-73-8$ & $-d$ & $-[29]$ & $\sqrt{ }$ & $\sqrt{ }$ & $\sqrt{ }$ & $\sqrt{ }$ & $\sqrt{ }$ & $\sqrt{ }$ \\
\hline$o$-Phenylphenol & $90-43-7$ & $+d$ & $+[27]$ & $\sqrt{ }$ & $\sqrt{ }$ & $\sqrt{ }$ & $\sqrt{ }$ & $\sqrt{ }$ & \\
\hline Diethyl phthalate & $84-66-2$ & $-{ }^{d}$ & $-[29]$ & & & & $\sqrt{ }$ & $\sqrt{ }$ & $\sqrt{ }$ \\
\hline Dimethyl phthalate & $131-11-3$ & $-{ }^{d}$ & $-{ }^{\mathrm{R}}$ & $\sqrt{ }$ & $\sqrt{ }$ & $\sqrt{ }$ & $\sqrt{ }$ & $\sqrt{ }$ & $\sqrt{ }$ \\
\hline Dibutyl phthalate & $84-74-2$ & $-{ }^{d}$ & $-[29]$ & $\sqrt{ }$ & $\sqrt{ }$ & $\sqrt{ }$ & $\sqrt{ }$ & $\sqrt{ }$ & $\sqrt{ }$ \\
\hline Biphenyl & $92-52-4$ & $-{ }^{d}$ & $+[29]$ & $\sqrt{ }$ & & & $\sqrt{ }$ & & $\sqrt{ }$ \\
\hline Dimethoate & $60-51-5$ & $+(-S 9)^{d}$ & $+[29]$ & & & & $\sqrt{ }$ & $\sqrt{ }$ & $\sqrt{ }$ \\
\hline Phenanthrene & $85-01-8$ & $-[26]^{c}$ & $-[29]$ & $\sqrt{ }$ & & & & & \\
\hline$N, N$-Diethyl- $m$-toluamide & $134-62-3$ & $-d$ & $-\mathrm{d}$ & & & & $\sqrt{ }$ & $\sqrt{ }$ & \\
\hline Bis(2-chloro-1-methylethyl)ether & $108-60-1$ & $+(-S 9,+S 9)[15]^{c}$ & $+[27]$ & & & & $\sqrt{ }$ & $\sqrt{ }$ & \\
\hline Benzophenone & 119-61-9 & $-d$ & $-{ }^{d}$ & $\sqrt{ }$ & $\sqrt{ }$ & $\sqrt{ }$ & $\sqrt{ }$ & $\sqrt{ }$ & $\sqrt{ }$ \\
\hline Dibenzofuran & $132-64-9$ & $-{ }^{d}$ & $-[29]$ & $\sqrt{ }$ & $\sqrt{ }$ & $\sqrt{ }$ & $\sqrt{ }$ & $\sqrt{ }$ & $\sqrt{ }$ \\
\hline Diphenylamine & $122-39-4$ & $-{ }^{d}$ & $-[29]$ & & $\sqrt{ }$ & & & & \\
\hline Acenaphthylene & $208-96-8$ & $-{ }^{\mathrm{R}}$ & ${ }^{\mathrm{R}}$ & & & $\sqrt{ }$ & $\sqrt{ }$ & & $\sqrt{ }$ \\
\hline Acenaphthene & $83-32-9$ & $-{ }^{d}$ & $+d$ & $\sqrt{ }$ & & & $\sqrt{ }$ & $\sqrt{ }$ & $\sqrt{ }$ \\
\hline Isoprothiolane & $50512-35-1$ & $-^{\mathrm{R}}$ & $+^{\mathrm{R}}$ & $\sqrt{ }$ & & $\sqrt{ }$ & $\sqrt{ }$ & $\sqrt{ }$ & $\sqrt{ }$ \\
\hline Acetophenone & $98-86-2$ & $-{ }^{d}$ & $+[29]$ & & & & & $\sqrt{ }$ & $\sqrt{ }$ \\
\hline Phenol & $108-95-2$ & $-[14]^{\mathrm{c}}$ & $+[27]$ & & & $\sqrt{ }$ & $\sqrt{ }$ & $\sqrt{ }$ & $\sqrt{ }$ \\
\hline Atrazine & $1912-24-9$ & $-[14]^{\mathrm{c}}$ & $+[27]$ & & $\sqrt{ }$ & & $\sqrt{ }$ & $\sqrt{ }$ & $\sqrt{ }$ \\
\hline Anthraquinone & $84-65-1$ & $+(-S 9)^{d}$ & $+d$ & $\sqrt{ }$ & & & $\sqrt{ }$ & $\sqrt{ }$ & $\sqrt{ }$ \\
\hline p-Cresol & $106-44-5$ & $-{ }^{d}$ & $+^{\mathrm{R}}$ & & & & & & $\sqrt{ }$ \\
\hline 2-Nitrophenol & $88-75-5$ & $-[14]^{\mathrm{c}}$ & $-{ }^{\mathrm{R}}$ & & & & & & $\sqrt{ }$ \\
\hline 2-Methylnaphthalene & $91-57-6$ & $-{ }^{\mathrm{R}}$ & $-^{\mathrm{R}}$ & $\sqrt{ }$ & & & & & \\
\hline 2,4-Dichlorophenol & $120-83-2$ & $-[15]^{\mathrm{c}}$ & $+[29]$ & & & & & $\sqrt{ }$ & \\
\hline 2,4,6-Trichlorophenol & $88-06-2$ & $-[14]^{\mathrm{c}}$ & $+[29]$ & & & & & $\sqrt{ }$ & \\
\hline 1,4-Dichlorobenzene & $106-46-7$ & $-[14]^{\mathrm{c}}$ & $+[27]$ & & & & $\sqrt{ }$ & $\sqrt{ }$ & $\sqrt{ }$ \\
\hline 1,2-Dichlorobenzene & $95-50-1$ & $-[26]^{\mathrm{c}}$ & $+d$ & & & & $\sqrt{ }$ & $\sqrt{ }$ & $\sqrt{ }$ \\
\hline 1,2,4-Trichlorobenzene & $120-82-1$ & $-[14]^{\mathrm{c}}$ & $+{ }^{d}$ & & & & & & $\sqrt{ }$ \\
\hline $1,2,4$-Trimethylbenzene & $95-63-6$ & $-{ }^{d}$ & $-{ }^{d}$ & & & & & & $\sqrt{ }$ \\
\hline Sum & & $6 / 39$ & $23 / 39$ & 15 & 12 & 11 & 26 & 27 & 27 \\
\hline
\end{tabular}

$\mathrm{R}$ indicates results obtained from read across for Ames test; $\sqrt{ }$ indicates that the pollutant was detected.

“+": positive; “-": negative.

Note: If conflicting results were obtained between documents and databases, only the positive results were taken, in accordance with the precautionary principle.

a DD, DNA-damaging effect.

b CA, chromosome-damaging effect.

c Results from SOS/umu test.

d Results from CCRIS database, Toxnet databases: Bacterial mutagenicity ISSSTY, carcinogenicity and mutagenicity ISSCAN, genotoxicity OASIS, micronucleus ISSMIC and toxicity Japan MHLW.

difference in the results possible. Moreover, for the six centralized Yangtze River source-waters, different types of genotoxicants were identified concurrently: six genotoxicants were found to be DNAdamaging agents and 23 were chromosome-damaging agents, respectively. The use of single bioassay could underestimate the potential genetic risk for not providing multiple aspects of information on genotoxicity, as screened in samples S2, S5, S5, S7, S8, S9, S10, S11, S12 and S16. It provides evidence of the need of bioassays not only for DNA-damaging but also for chromosome-damaging effects in the comprehensive determination of the genotoxic potential of a mixture.

In conclusion, the present study found that all the centralized source-waters were more or less genotoxic using a combined bioassay including SOS/umu test and a flow cytometry-based MN assay. In addition, differences in mechanisms and mode of action in expressing genotoxicity were found for different samples, as well as aneugenic and clastogenic modes of action in the formation of MN. These results indicate that a combination of the SOS/umu test and the MN assay to detect both DNA damage and chromosome damage could be incorporated into a monitoring system to comprehensively evaluate the genotoxicity of complex mixtures. In addition, with the help of GC/MS and the QSAR Toolbox, several genotoxicants were found in the six selected samples, and $o$-phenylphenol was initially identified as a major contributor to the DNA-damaging effect while PAHs, pesticides, phenol and anthraquinone were found to be the predominant chromosomedamaging agents in these samples.

\section{Conflict of interest}

None declared. There is no conflict of interest.

\section{Acknowledgements}

This work was financially supported by the National Natural Science Foundation of China (Grant No. NSFC 51290283), the National High-tech R\&D Program of China (863 Program, Grant No. 2012AA06A302) and the National Natural Science Foundation of China (Grant No. NSFC 21307131). Thanks also to Mrs. Li Qiao and Dr. Wang Chao. 


\section{References}

[1] P.H. Gleick, China and water, in: P.H. Gleik, H. Cooley, M.J. Cohen, M. Morikawa, J.P.M. Morrison (Eds.), The World's Water 2008-2009: The Biennial Report on Freshwater Resources, Island Press, Washington, 2009, pp. 79-100.

[2] X.-J. Zhang, C. Chen, P.-F. Lin, A.-X. Hou, Z.-B. Niu, J. Wang, Emergency drinking water treatment during source water pollution accidents in china: origin analysis, framework and technologies, Environ. Sci. Technol. 45 (2010) 161-167.

[3] R. Wu, S.S. Qian, F. Hao, H. Cheng, D. Zhu, J. Zhang, Modeling contaminant concentration distributions in China's centralized source waters, Environ. Sci. Technol. 45 (2011) 6041-6048.

[4] W. Jiang, Y. Yan, N. Li, M. Ma, D. Wang, K. Rao, Z. Wang, S.K. Satyanarayanan, Retinoid X receptor activities of source waters in China and their removal efficiencies during drinking water treatment processes, Chin. Sci. Bull. 57 (2012) $595-600$.

[5] W. Shi, F.X. Zhang, G.J. Hu, Y.Q. Hao, X.W. Zhang, H.L. Liu, S. Wei, X.R. Wang, J.P. Giesy, H.X. Yu, Thyroid hormone disrupting activities associated with phthalate esters in water sources from Yangtze River Delta, Environ. Int. 42 (2012) $117-123$.

[6] Y.-Q. Li, Y.-L. Wu, Y.-G. Chen, Z.-M. Kong, Genotoxicity evaluation and a primary risk assessment of organic pollutants in the drinking water sources of Nanjing, China J. Environ. Sci. 18 (2006) 983-988.

[7] X. Tao, H. Zhu, G.M. Matanoski, Mutagenic drinking water and risk of male esophageal cancer: a population-based case-control study, Am. J. Epidemiol. 150 (1999) 443-452.

[8] X.G. Tao, H.G. Zhu, S.Z. Yu, Q.Y. Zhao, J.R. Wang, G.D. Wu, X.F. You, C. Li, W.L. Zhi, J.P. Bao, Pilot study on the relationship between male stomach and liver cancer death and mutagenicity of drinking water in the Huangpu River area, Public Health Rev. 19 (1991) 219-227.

[9] Guidance on genotoxicity testing and data interpretation for pharmaceuticals intended for human use S2(R1), ICH2011, pp. 1-25.

[10] C.P.a.t.e.C. Committee on Mutagenicity of Chemicals in Food, Guidance on a Strategy for Testing of Chemicals for Mutagenicity, 2000, pp. 1-36.

[11] B. Žegura, E. Heath, A. Černoša, M. Filipič, Combination of in vitro bioassays for the determination of cytotoxic and genotoxic potential of wastewater, surface water and drinking water samples, Chemosphere 75 (2009) 1453-1460.

[12] F. Ma, G. Yuan, L. Meng, Y. Oda, J. Hu, Contributions of flumequine and nitroarenes to the genotoxicity of river and ground waters, Chemosphere 88 (2012) 476-483.

[13] Y. Oda, S.-i. Nakamura, I. Oki, T. Kato, H. Shinagawa, Evaluation of the new system (umu-test) for the detection of environmental mutagens and carcinogens, Mutat. Res. 147 (1985) 219-229.

[14] G. Reifferscheid, J. Heil, Validation of the SOS/umu test using test results of 486 chemicals and comparison with the Ames test and carcinogenicity data, Mutat. Res. 369 (1996) 129-145.

[15] K. Yasunaga, A. Kiyonari, T. Oikawa, N. Abe, K. Yoshikawa, Evaluation of the Salmonella umu test with 83 NTP chemicals, Environ. Mol. Mutagen. 44 (2004) 329-345.

[16] S.M. Bryce, S.L. Avlasevich, J.C. Bemis, S.D. Dertinger, Miniaturized flow cytometry-based CHO-K1 micronucleus assay discriminates aneugenic and clastogenic modes of action, Environ. Mol. Mutagen. 52 (2011) 280-286.

[17] P. Fowler, R. Smith, K. Smith, J. Young, L. Jeffrey, D. Kirkland, S. Pfuhler, P. Carmichael, Reduction of misleading (false) positive results in mammalian cell genotoxicity assays: II. Importance of accurate toxicity measurement, Mutat. Res. 747 (2012) 104-117.

[18] P. Fowler, K. Smith, J. Young, L. Jeffrey, D. Kirkland, S. Pfuhler, P. Carmichael, Reduction of misleading (false) positive results in mammalian cell genotoxicity assays: I. Choice of cell type, Mutat. Res. 742 (2012) 11-25.

[19] A. Hartmann, A.C. Alder, T. Koller, R.M. Widmer, Identification of fluoroquinolone antibiotics as the main source of umuc genotoxicity in native hospital wastewater, Environ. Toxicol. Chem. 17 (1998) 377-382.
[20] M.J. Gómez, M.M. Gómez-Ramos, A. Agüera, M. Mezcua, S. Herrera, A.R. Fernández-Alba, A new gas chromatography/mass spectrometry method for the simultaneous analysis of target and non-target organic contaminants in waters, J. Chromatogr. A 1216 (2009) 4071-4082.

[21] W. Elisabeth, F. Birgit, H. Peter-Diedrich, in: Genotoxicity Assay: umu-Test (ISO/DIS 13829, 2000), ISO/CD 13829, International Organization for Standardization (ISO), Berlin, Germany, 1998.

[22] R.Y. Xiao, Z. Wang, C.-X. Wang, G. Yu, Y.-G. Zhu, Genotoxic risk identification of soil contamination at a major industrialized city in northeast China by a combination of in vitro and in vivo bioassays, Environ. Sci. Technol. 40 (2006) 6170-6175.

[23] H. Doostdar, S.J. Duthie, M.D. Burke, W.T. Melvin, M.H. Grant, The influence of culture medium composition on drug metabolising enzyme activities of the human liver derived Hep G2 cell line, FEBS Lett. 241 (1988) 1518.

[24] OECD, OECD Guideline for the Testing of Chemicals Draft Proposal for a New Guideline 487: In Vitro Mammalian Cell Micronucleus Test (MNvit), 2009, pp. $1-24$.

[25] S.M. Bryce, S.L. Avlasevich, J.C. Bemis, M. Lukamowicz, A. Elhajouji, F. Van Goethem, M. De Boeck, D. Beerens, H. Aerts, J. Van Gompel, J.E. Collins, P.C. Ellis, A.T. White, A.M. Lynch, S.D. Dertinger, Interlaboratory evaluation of a flow cytometric, high content in vitro micronucleus assay, Mutat. Res. 650 (2008) $181-195$

[26] O.f.E.C.-o.a.D.a.E.C, in: Agency, Strategies for Grouping Chemicals to Fill Data Gaps to Assess Genetic Toxicity and Genotoxic Carcinogenicity, 2011.

[27] M. Rajagopalan, C. Lu, R. Woodgate, M. O‘Donnell, M.F. Goodman, H. Echols, Activity of the purified mutagenesis proteins UmuC, UmuD', and RecA in replicative bypass of an abasic DNA lesion by DNA polymerase III, Proc. Natl. Acad. Sci. 89 (1992) 10777-10781.

[28] C.J. Kenyon, The bacterial response to DNA damage, Trends Biochem. Sci. 8 (1983) 84-87.

[29] Nanjing Municipal Environmental Monitoring Center (NMEM Center), in: The Survey and the Solution of Organic Pollutants in the Source Water of Nanjing City, N.E.P.B.o., Nanjing, 2003.

[30] J.-Y. Wu, Assessing surface water quality of the Yangtze Estuary with genotoxicity data, Mar. Pollut. Bull. 50 (2005) 1661-1667.

[31] T. Ohe, T. Watanabe, K. Wakabayashi, Mutagens in surface waters: a review, Mutat. Res. 567 (2004) 109-149.

[32] F. Maffei, F. Carbone, G.C. Forti, A. Buschini, P. Poli, C. Rossi, L. Marabini, S. Radice, E. Chiesara, P. Hrelia, Drinking water quality: an in vitro approach for the assessment of cytotoxic and genotoxic load in water sampled along distribution system, Environ. Int. 35 (2009) 1053-1061.

[33] S. Knasmüller, V. Mersch-Sundermann, S. Kevekordes, F. Darroudi, W.W. Huber, C. Hoelzl, J. Bichler, B.J. Majer, Use of human-derived liver cell lines for the detection of environmental and dietary genotoxicants; current state of knowledge, Toxicology 198 (2004) 315-328.

[34] W.M.A. Westerink, T.J.J. Schirris, G.J. Horbach, W.G.E.J. Schoonen, Development and validation of a high-content screening in vitro micronucleus assay in $\mathrm{CHO}_{-}$ k1 and HepG2 cells, Mutat. Res. 724 (2011) 7-21.

[35] G. Li, X. Xia, Z. Yang, R. Wang, N. Voulvoulis, Distribution and sources of polycyclic aromatic hydrocarbons in the middle and lower reaches of the Yellow River, China, Environ. Pollut. 144 (2006) 985-993.

[36] X. Luo, B. Mai, Q. Yang, J. Fu, G. Sheng, Z. Wang, Polycyclic aromatic hydrocarbons (PAHs) and organochlorine pesticides in water columns from the Pearl River and the Macao harbor in the Pearl River Delta in South China, Mar. Pollut. Bull. 48 (2004) 1102-1115.

[37] C. Feng, X. Xia, Z. Shen, Z. Zhou, Distribution and sources of polycyclic aromatic hydrocarbons in Wuhan section of the Yangtze River, China, Environ. Monit. Assess. 133 (2007) 447-458. 